\title{
Factors of Quality of Life in a Group of Selected European Union and OECD Countries
}

\section{Czynniki jakości życia w grupie wybranych krajów Unii Europejskiej i OECD}

\author{
Magdaléna Drastichová*, Peter Filzmoser** \\ *Technical University of Ostrava, Czechia \\ E-mail: magdalena.drastichova@vsb.cz \\ **Vienna University of Technology, Austria \\ E-mail:peter.filzmoser@tuwien.ac.at
}

\begin{abstract}
This work focuses on the evaluation of the factors of quality of life in a sample of 26 countries. Quality of life is a complex, multidimensional concept, which includes various social, cultural, economic, political, demographic and environmental aspects. Regarding this, principal component analysis and regression analysis were chosen as relevant methods to analyse relationships among twenty-five variables related to quality of life, and their relationships with three composite indices reflecting crucial aspects of quality of life, wellbeing and sustainability. These indices, applied as the response variables in the regression analysis, include the inequality-adjusted alternative of the Human Development Index (IHDI), the Happy Planet Index (HPI), and Healthy Life Years (HLY). The IHDI represents an objective indicator of human development and wellbeing. HLY reflects quality of life in terms of health. The HPI combines the ecological efficiency with which human wellbeing is delivered, while it also includes a subjective measure of wellbeing. Since each of these indices represent different aspects of quality of life to a certain extent, some of the factors (represented by selected indicators) affected them in different ways. After applying a Lasso regression, nine of the 25 indicators - representing crucial factors of quality of life - were identified. Homicide rate (representing the factor of safety) affected all three indices in a negative way, whereas Years in education (representing the factor of education) and Life satisfaction - a subjective indicator of wellbeing representing the dimension of the same name, affected them positively.
\end{abstract}

Key words: health, human development, quality of life, sustainable development, regression analysis, principal component analysis. JEL Classification: I10, I13, I15, I18, Q01.

\section{Streszczenie}

Niniejsza praca koncentruje się na ocenie czynników jakości życia na próbie 26 krajów. Jakość życia to złożone, wielowymiarowe pojęcie, które obejmuje różne aspekty społeczne, kulturowe, ekonomiczne, polityczne, demograficzne i środowiskowe. W związku z tym wybrano analizę głównych składowych i analizę regresji jako odpowiednie metody analizy relacji między 25 zmiennymi odnoszącymi się do jakości życia oraz ich związków z trzema złożonymi wskaźnikami odzwierciedlającymi kluczowe aspekty jakości życia, dobrostanu i zrównoważonego rozwoju. Wskaźniki te, stosowane jako zmienne odpowiedzi w analizie regresji, obejmują skorygowaną o nierówności alternatywę wskaźnika rozwoju społecznego (IHDI), wskaźnika szczęśliwej planety (HPI) i wskaźnika lat zdrowego życia (HLY). IHDI stanowi obiektywny wskaźnik rozwoju człowieka i dobrobytu. HLY odzwierciedla jakość życia w kategoriach zdrowia. HPI łączy w sobie efektywność ekologiczną, z jaką zapewnia dobrostan człowieka, a także subiektywna miare dobrostanu. Ponieważ każdy z tych wskaźników w pewnym stopniu reprezentuje różne aspekty jakości życia, niektóre czynniki (reprezentowane przez wybrane wskaźniki) wpływały na nie w różny sposób. Po zastosowaniu regresji Lasso zidentyfikowano dziewięć z 25 wskaźników - reprezentujących kluczowe czynniki jakości życia. Wskaźnik zabójstw (będący czynnikiem bezpieczeństwa) wpłynął negatywnie na wszystkie trzy wskaźniki, natomiast lata nauki (będące czynnikiem wykształcenia) i zadowolenie z życia - subiektywny wskaźnik dobrostanu reprezentujący wymiar o tej samej nazwie - wpłynęły na nie pozytywnie.

Słowa kluczowe: zdrowie, rozwój człowieka, jakość życia, zrównoważony rozwój, analiza regresji, analiza głównych składowych 


\section{Introduction}

Improving the quality of life for individuals around the world is a crucial goal. However, the means to achieve it, or even to accurately measure it, remain elusive. Quality of life may be considered on various geographic scales. Nevertheless, it is the individual that truly matters, and each person has the right to their share of wellbeing (at the lowest analytical level, which is the individual) (Cusack, 2019). Quality of life needs to be put into the context of sustainable development (SD). Most generally, improving the quality of life of the current generation should not impose a burden on future generations and limit their quality of life and wellbeing. This complies with the basic philosophy of SD. The SD paradigm emerged to provide a framework by which economic growth, social welfare, and environmental protection can be harmonized (Asara et al., 2015). According to its essential definition, by which SD was conceptualized, it is development that meets the needs of the present without compromising the ability of future generations to meet their own needs (WCED, 1987). Later on, its definition was explicated as a development that generates economic growth, distributes benefits equitably, regenerates the environment, and promotes people (Mosteanu et al., 2014). Based on this, the concept of SD addresses the issue of inequity, and complements desires for economic and environmental vitality. Since this definition was accepted, many further definitions, methods of measurement, and parameters have been developed. The concept of SD can then be interpreted as a balance between its pillars, i.e. the economic, social and environmental pillar (see more also in Drastichova (2018); Drastichova and Filzmoser, 2019). Moreover, the fourth, institutional dimension is emphasized as the fourth pillar of SD because of its necessity in supporting progress in the previous three pillars and in SD generally (United Nations et al., 2003). The relationship to quality of life is obvious. The concept of SD concerns environmental protection, economic vitality, as well as social equity (by assimilating individual concerns into collective ones). This balance between the three E's of sustainability, as well as between the collective and the individual, have made $\mathrm{SD}$ one of the great challenges. It also reflects the fact that the quality of life of future generations will depend on our current decisions. Transferring our attention to quality of life in the context of SD, hundreds of definitions of SD have been presented over recent decades (deVries and Petersen, 2009). In an effort to summarize these definitions, and to emphasise the interdisciplinary nature of sustainability, they themselves define SD as a quest for developing and sustaining qualities of life. According to Cusack (2019), awareness of the need for SD is increasing throughout the world. The goals of SD, oriented around the three E's, namely: economic growth, environmental protection, and social equity, also correlate with quality of life considerations.

The concepts of quality of life and SD are significantly interconnected, and in an analysis of quality of life not only SD but additional (related) concepts should be taken into account. Recently there has been a focus on the concept of human development (HD) together with several alternative (transformation) concepts, which should also be considered in relation to quality of life. As regards the human development approach, the current focus on the economic, environmental and social dimensions of SD must be expanded so as to include a human dimension. This focuses on people and their opportunities and choices and is therefore a crucial part of the overall concept of SD, and must be considered when analysing quality of life. The concept of HD is considered in this work and therefore it is necessary to explain it in more detail. Ideas of HD have become strongly associated with the work of the United Nations Development Programme (UNDP), and the publication of their annual reports (UNDP, 1990). The HD paradigm supports a need for understanding development as being development of the people by the people, for the people (UNDP, 2020). The contribution of HD can be understood in a consideration of development that has moved away from a purely economic-based understanding measured in GDP, and from a purely state-centred understanding, to one where the people become the main agents of development. A number of transformation discourses, such as the concepts of degrowth or Buen Vivir, have arisen (Beling et al., 2017). Practical application of the principles of these concepts can significantly affect quality of life. Primarily, the rationale behind this research lies in a consideration of the concept of SD (and related concepts) and its adoption as a basic philosophy. The growing importance of alternatives to SD is also considered.

The term quality of life (similarly to the concept of SD) is difficult to define, identify, categorize and analyse. It is a complex, multidimensional concept and includes various social, cultural, economic, political, demographic and environmental aspects. Based on this conception, further consideration should be given to what determines quality of life, with respect to the basic philosophy of SD (more in section 2.1). The WHO Quality of Life (WHOQOL) Group defines quality of life as the perceptions of individuals with regard to their own personal goals and expectations, their standards, and their concerns (Feng and Hsieh 2009). An emphasis on the individual is included in this definition. An emphasis on the individual is included in this definition. As inequities persist, individual wellbeing remains elusive for many. Although quality of life at a national level is the main area of interest in this work, the importance of individuals is not neglected.

Quality of life, which should result, ultimately, from $\mathrm{SD}$, is, like SD, a global challenge. The main philosophy of SD, according to its most commonly quoted definition, is considered. The quality of people's lives at a national level is the main area of interest in this work, which considers the basic philosophy of SD. The aim of this work is to identify the crucial factors affecting quality of life, and to discover the relationships between these factors in a sample of 26 
developed OECD countries. The sample includes the EU countries (apart from Malta, Croatia, Cyprus, Bulgaria, and Romania) along with several non-EU countries, which are OECD members, including Iceland, Norway, Switzerland, and the UK. Regarding statistical methods, principal component analysis and regression analysis are applied. We posed two main research questions. Firstly, if there are many factors of quality of life, are some of them more significant than the others? Is health and subjective indicators among the most important factors of quality of life and SD?

Since the main philosophy being considered is SD, the variables applied were chosen to reflect aspects of sustainability, SD, wellbeing and quality of life, taking the human development approach into account. To this end, several composite indices reflecting crucial aspects of sustainability, SD, and quality of life, are selected for the analysis. These variables reflect quality of life in conjunction with SD. Namely, the Inequality-adjusted Human Development Index (IHDI), the Happy Planet Index and Healthy Life Years were chosen for this purpose. The selection of the main factors of quality of life to be used as explanatory variables in the regression analysis is determined by a detailed analysis of a number of works by other authors. Next, the relationships between these factors and the composite indices are analysed in order to determine the essential factors of quality of life and SD at a national level. To sum up, in the selection of all variables, the essential aspects and factors of both quality of life and SD are taken into account, based on detailed studies and analysis of relevant research works.

The structure of the remainder of this paper is as follows: Section 2 discusses more background to the topic and provides information to the data and to the statistical methods; Section 3 provides the results and discusses the findings; Section 4 contains overall discussions in the context, and Section 5 finalizes the paper with conclusions.

\section{Materials and Methods}

In this section, the works most relevant to the performed analysis are briefly introduced. Subsequently, the data and methods applied are described.

\subsection{Literature Review}

At the beginning, important studies focusing on the history of the concept of quality of life are introduced. Philosophers have been debating the merits of measuring the quality of human life in terms of utility, whether understood as happiness or as the satisfaction of desires or preferences. Some philosophers continue to defend this general approach albeit usually with considerable qualifications, adopting utilitarian stances with complex and subtle restrictions on the nature of the preferences that may be considered. Others have concluded that the whole utilitarian approach should be rejected and replaced, perhaps, by an account of the many different kinds of activity that actually make up a thriving human life. According to Sinha (2019), the concept of the quality of life is multidisciplinary and as such, it is holistic, since it incorporates every aspect of a human's daily life in its compass. It is not exclusively economic; rather, it has social, political, cultural, and recreational underpinnings. Contributors of the chapters of that work have attempted to elucidate the meaning of the quality of life in their respective countries through their valued contributions.

The work of Seth (1889) was probably the first in the history of development of the concept of quality of life. While discussing the nature of ethical end or standard as social welfare, the author stated that in order to an ethical theory, we must not regard the mere quantity, but also the quality, of the 'life' which forms the moral end (Seth, 1889). He postulated that both the quantity and quality of life should be considered from the perspective of promoting welfare activities to enhance happiness or quality of life of individual members. After integrating the literature concerning the definition and measurement of quality of life, Elyse (1992) found that the concept of quality of life was newer in comparison to the concept of public happiness which was popularly used as a measurable quantity by the political economists in the past. The author indicated that the wider use of quality of life started from 1961. Initially, the term was used most often in conjunction with such concerns as environmental pollution or urban deterioration. This is the context which is now considered on a much broader scale and has received greater attention by scholars and researchers of different disciplines at the global level. The idea of Meeberg (1993) is similar to the ideas of the previous author. He also considered quality of life as a phrase which was first used shortly after the Second World War and has been overused and infrequently defined since then. Most of the attempts to deal with quality of life took place in the 1960s. Besides that explained above, Farquhar (1995) emphasised the fact that from the mid-1970s the term clinical interventions concerning health was also used in the area of medical science along with the increasing importance and use of quality of life in social science. However, medicine and nursing science predominantly focused on quality of life related to health to examine only one domain of quality of life, i.e. physical functioning.

The concept of quality of life is broad, crossing three major branches of science: economics, medicine and the social sciences, with each branch providing different views on the conceptualisation of quality of life (Cummins, 2005). From the social science perspective, quality of life has, in particular, been conceptualised firstly as multidimensional (that is influenced by personal and environmental factors and their interactions), secondly, as having the same components for all people, thirdly, as having both subjective and objective components, and, finally, as being enhanced by self-determination, resources, purpose in life, and a sense of belongingness (Cummins, 2005). Such conceptualization has made quality of life an elusive and diverse concept approached 
with varying levels of generality - from the assessment of societal or community wellbeing, to the evaluation of the wellbeing of specific groups and individuals. This also makes the quality of life a multidimensional concept that needs to be carefully defined by using different attributes or indicators, and in which the inclusion of indicators should be based on the context in which quality of life is being used. Several taxonomies of quality of life have been developed. Ferrans (1996), and Felce and Perry (1995, 1996) were the first to endorse the search for suitable indicators to conceptualise the idea. Felce (1997) stated that quality of life is influenced by six main elements, including material, physical, emotional, social, productive, and rights/civic wellbeing. On the other hand, the World Health Organisation (WHO) categorised quality of life into six components, which are physical wellbeing, environmental wellbeing, psychological wellbeing, social relations, level of independence and spiritual wellbeing. In this context, wellbeing is defined as the state of being happy, healthy and comfortable with life (WHO, 1997; Galloway 2006). However, from the point of view of Social Science, quality of life generally implies the overall satisfaction of person's living. This satisfaction may arise from economic attributes (related more to material goods), social attributes (linked to psychological satisfaction) and environmental attributes (connected with accessibility to desired natural and physical conditions). It results from these attributes that quality of life has different dimensions which are either objective or subjective. The objective dimensions of quality of life are usually physical attributes that may be in the form of quantities and frequencies of an entity, for example, access to good housing, infrastructure and services, healthy food, etc. (Cummins, 2005). The subjective dimensions are within the private consciousness of each individual and can be verified only through repeated responses provided by the person concerned. The subjective dimensions are within the private consciousness of each individual and can be verified only through repeated responses provided by the person concerned. These objective and subjective dimensions have further been widely discussed in different works, such as Felce (1997), Haas (1999), Moons et al. (2006), Testa and Simonson (1996), or Sirgy (1998).

Sirgy (1998) indicated that the subjective dimension of person's quality of life can arise from either needbased-expectations (materialist) or cognitive-based expectations (non-materialist), or both. The needbased-expectation tends to be influenced by social comparisons, such as wealth and material possession of family and friends, while the cognitive-based-expectations arise via predictive-, past- and abilitybased comparisons. With the emergence of postmodernism thought there has been a growing concern that quality of life is purely a subjective experience (Haas et al., 2006; Haas, 1999). Thus, it is socially constructed. The other common view is that quality of life should not be primarily defined with regard to either its objective or subjective components but should rather include both aspects (Cummins, 2005) as they both affect the quality of an individual's life. This is particularly true when the quality of life is identified as a measure of collectivises, such as assessing the quality of life at a community level, local level or at a regional or national level.

As mentioned above, the concept of quality of life is difficult to define and analyse. The quality of life of people of an area can be studied at any spatial level such as the local, regional, national and international level. It can also be studied across social structures. The quality of life of any person living in a defined region at a particular point in time is a composite picture of several objective and subjective or quantitative and qualitative variables. Nevertheless, quality of life does not remain the same throughout a person's life, but it varies from one stage of life to another, and from one type of spatial unit to another, because every aspect of the life of a person is influenced by the environment (Sinha, 2019). Prutkin (2002) explained some constraints on the measurement of quality of life. He stated that assessment of quality of life is a difficult task due to the involvement of several elements/factors of a varied nature, role and importance, and the selection and applicability of indicators. Saxena et al. (1998) also expressed some limitations concerning the measurement of quality of life. According to them, the idiom quality of life is frequently used as a concept but it is very vague, because it involves diverse social, cultural, economic, regional and other aspects and thus, the measurement of quality of life in a precise form remains elusive.

Rodrigues et al. (2020) presented the reference framework for multidisciplinary research at the Life Quality Research Centre (LQRC). The research paradigm about the people's quality of life in society imposes a multifaceted and complex analysis. At the LQRC it is thematically divided into six scientific areas: education and training; physical activity and healthy lifestyles; food production and technology on food behaviors; organizational dynamics; motor behavior; and individual and community health. According to them, research on people's quality of life is a cross-cutting, multidisciplinary, and fundamental issue concerning current society. Contemporary societies focus on the physical, psychological, and social wellbeing of the population. This should be translated into relevant policies. The idea of quality of life is closely related to SD (Rodrigues et al., 2020).

Jones and John (1977) applied some criteria in measuring quality of life, such as per capita and household income, unemployment rate, housing cost, infant mortality, suicide rate, robbery, traffic rate, voting in presidential election, etc. According to Ginsberg (1980) the variation in qualitative features of the inhabitants in a given area significantly determines the variation in the pattern of economic growth in this area. This results from the fact that the qualitative attributes of people in a given area play a great role in the process of increasing the level of peace, progress, prosperity and, in turn, quality of life. Mittal (1993) 
and Ghosh (1993) dealt with the role of literacy, education, and equitable distribution of resources in raising people's quality of life. Rajesh (1993) and Ramaswami and Ram (1985) discovered the importance and role of the quality of human resource (knowledge, skills, attitudes, vigour, attitude, capacity, etc.) and the development of human resources through formal and non-formal education, training, food and nutrition, etc. in maintaining and increasing the quality of life of the people. They also included indicators of habits, culture, environment, standard of living, number of children, expenditure towards children's education and health awareness, etc. to reflect destitution and condition of life. Qasim (1993) stated that in fact, GNP or per person income do not truly help in meeting the basic needs of people. Moreover, maintenance of ecological balance and human rights are as important as the other basic needs. A real improvement in quality of life will be hard to achieve unless the question of population control is aggressively pursued and some degree of stability is ensured (with regard to various aspects of human needs and quality of life issues). There is the highest urgency for the implementation of two components, i.e. literacy and availability of energy from the point of view of improvement of quality of life. According to Park (2009), standard of living and quality of life are fundamentally different concepts. Standard of living basically results from materialbased resources and opportunities measured by objective indicators, whereas quality of life is the result of a persons' subjective assessment about their life. Then, the measurement of quality of life is based solely on personal opinion and evaluation about satisfaction in their life. The most appropriate approach for measuring quality of life is the application of a composite index, which is calculated on the basis of the sum of values of a variety of physical and mental health and other aspect-related indicators. The basic objective of this is to form a picture of the peace, comfort, and happiness of a life.

Singh (1993) considered income, employment, health, education, physical environment, human dignity and freedom as quantitative and qualitative indicators in measuring quality of life of the people. Life expectancy at birth, infant mortality rate, crude death rate, literacy rate, per capita income, number of hospitals and dispensaries, telephone exchange, post and telegraph office, per capita availability of food grains, population covered by radio, TV were taken into account by Sarma et al. (1993) as indicators of quality of life. Hussain (1994) has also took into consideration population characteristics such as infant mortality, expectancy of life and literacy as crucial factors of physical quality of life. He also used GNP per capita, education and health in evaluating physical quality of life of the targeted population. Rajev (2006) pointed out that the spatial variation in the distribution of different urban social groups determines both urban landscape features, such as building density and house types, and differences in quality of life.
Smith (1977) considered different elements relating to improvement of the material quality (housing condition, resources), physical quality (health, reduced violence, preservation of the natural environment), mental quality (education, knowledge, cultural environment) and improvement in the spiritual quality (talents and capabilities, social harmony, moral and ethical stands) of life. Further, he prepared a list of several indicators relating to ecological, demographic, social, cultural, economic, environmental aspects in measuring the status of life quality of the inhabitants of a concerned region. Based on the various views (also outlined above), the housing represents a social establishment where the satisfaction of life mainly depends upon. Moreover, it has both social and spatial dimensions. Perera and Mensah (2019) investigated the way in which people utilised housing affordability as a reflexivity of their expectation for quality of life over time and space. Based on the systematic review method, a total of 227 publications that focused on quality of life and housing affordability were reviewed.

Special attention has to be paid to the relationship between quality of life and SD. Quality of life addresses peoples' perceptions of their position in life in relation to their culture, values, and expectations. Achieving progress in quality of life through SD, particularly at the city level, requires careful planning which is both place and culture specific and that involves community and citizen input. Improving quality of life and meeting the needs of the present through SD will help ensure greater likelihood of likewise accommodating the needs of future generations (Cusack, 2019). The parallels between quality of life and SD are unambiguous. Cusack (2019) also concluded that quality of life addresses peoples' perceptions of their position in life in terms of their culture and values and in relation to their goals and expectations. In compliance with that, quality of life is crucial for sustainability, as the essence of sustainability is basically considered to be about people's standards and concerns (Bell and Morse, 2008). The concept of SD should help develop means to accommodate future populations while at the same time improving qualities of life. According to Feng and Hsieh (2009) the concepts of quality of life and SD are similar. Fundamentally, sustainability is a concept which has central status to quality of life for present and future generations (Bijl, 2011). Then, sustainability, can be understood as a state where the key goals of SD are satisfied, a high quality of life is achieved, and the environment is preserved (Fischer and Adjo 2011). It is important to note that if people are not satisfied with their current quality of life, it cannot be expected that they will make sacrifices that may potentially benefit future generations. This means that SD strategies must address present-day wellbeing in addition to that of future generations (Morrill, 2011). Since progress in quality of life and progress in SD are mirroring processes, there are also shared constraints in terms of assessment and achievement. Especially, concepts of wellbeing and 
sustainability are influenced by culture. Accordingly, relevant literature, emphasizes the need for greater cultural awareness and heightened intercultural dialog, while noting that different people hold different views of the environment (Gambini, 2006; Pellicer, 2008).

As regards the possibilities of measurement of quality of life reflecting the aspects of sustainability and $\mathrm{SD}$, the results of several studies need to be mentioned. Although the concepts of quality of life and sustainability/SD are somewhat vague in meaning, and certain to vary from person to person and place to place, there are similarities in the tools used for measuring them. Currently, indicators of quality of life are widely tied with the concept of SD and create an important part of it (Lotfi et al., 2011). However, both can be defined and measured in a variety of ways. According to Cusack (2019), using measures such as the life satisfaction rating and the Human Development Index (HDI), both available from the UNDP, a positive correlation between self-assessed well-being and overall life satisfaction has become evident. The UNDP also provides an environmental performance index, which similarly correlates with wellbeing at both national- and city-specific levels. This knowledge is relevant for (and applied in) our study and the inequality-adjusted alternative of HDI, which is the inequality-adjusted HDI (IHDI), is used as one of the investigated composite indices, reflecting some aspects of both quality of life and SD (and wellbeing). With respect to methodological aspects, there are studies which apply an objective approach and statistically analyse variables that are considered to influence quality of life. However, there are also studies which apply a subjective approach to their analysis (see particular initiatives in Cusack, 2019). The Subjective Well-Being (SWB) approach assesses quality of life by simply asking people how un/happy and dis/content they are with their life (de Vries and Petersen, 2009). Many studies have focused on the dimensions of quality of life and SWB (Botha, 2016). The HD Report published by the UNDP also includes an overall life satisfaction rating by country. Such a ranking is based on self-perceptions of wellbeing, with the specific survey question being posed as such: Please imagine a ladder, with steps numbered from zero at the bottom to ten at the top (UNDP, 2011).

Cusack (2019) demonstrated that quality of life follows a general economic trend. Those countries with the greatest professed life satisfaction and scoring toward the top of the ladder are typically those categorized as having very high human development. The correlation between HDI scores and self-assessed wellbeing scores was confirmed. The simultaneous upward trends of these indicators indicate that overall life satisfaction is clearly influenced by such variables as health, education, and wealth. Since the standard of living concept focuses on economic welfare and quality of life includes culture, religious aspects, and the environment, such coinciding trends are of great importance (Ioncică and Petrescu 2016).
In order to determine the extent of relationships between the environment and quality of life, the wellbeing variable was evaluated in relation to the Environmental Performance Index (EPI). The EPI is used as a composite measure of sustainability and it covers both the environmental public health and ecosystem vitality (UNDP, 2011). The association between the EPI and self-assessed wellbeing was also demonstrated in Cusack (2019). The association between the two variables can indicate that the quality of the environment has an impact on the quality of life. This reinforces the principles of SD and the need for inclusion of the environment into any economic agenda. A positive general linkage between wellbeing and EPI was confirmed. Countries with higher EPI scores typically demonstrate higher overall life satisfaction scores. Overall life satisfaction is positively correlated with both HDI and environmental performance. Accordingly, neither the environment nor the economy can be sacrificed at the expense of the other; a fact which has significant policy implications.

Moreover, increases in income alone have played only a limited role in happiness. There are other variables which influence perceptions of wellbeing, such as health, environment, family, or freedom (de Vries and Petersen 2009). Finally, it can be confirmed that many of the relevant aspects of quality of life is difficult to quantify economically, including the intrinsic value of nature. The focus should be on holistic development that considers equity and the environment in conjunction with economic growth. The difference between economic growth and economic prosperity makes a critical distinction (economic growth being frequently associated with monetary aspects and prosperity as a broader term including the nonmonetary aspects of quality of life). A necessity of the prosperity to be sustained and inclusive has been acknowledged (Greenwood and Holt, 2010). It has also been recognized that income or other objective indices of wealth are not necessarily associated to increased quality of life.

The knowledge presented in this section forms the basic foundation of this work. Overall, all the previous works inspired this study in terms of the selection of factors and indicators (variables) reflecting quality of life.

\subsection{Data and Methodology}

The background, indicators used, data sources and methodology are defined in this section.

\subsubsection{Data}

On the basis of the knowledge obtained from the study of relevant works, three composite indicators were chosen to reflect crucial aspects of quality of life, sustainability (SD) and wellbeing. These are composite indicators, i.e. indices involving several indicators, which reflect important factors and areas of quality of life and wellbeing, as well as crucial dimensions of SD. Their choice is justified by the relevant works (see section 2.1). 
Firstly, economic and social development, or human wellbeing, can be approximated with UNDP's widely recognized HDI and its inequality-adjusted alternative, IHDI. IHDI, which is even a more suitable measure than HDI, combines a country's average achievements in health, education and income with the distribution of those achievements among country's population by discounting each dimension's average value according to its level of inequality (UNDP, 2020). It can be interpreted as the level of human development when inequality is considered. The relative difference between the IHDI and HDI is the loss due to inequality in distribution of the HDI within the country. The IHDI goes beyond the average achievements of a country in health, education and income to show how these achievements are distributed among its residents (UNDP, 2015). Thus, this index better reflects the aspects of SD and wellbeing, as well as those of quality of life. The HDI is calculated as a geometric mean of the three dimension indices according to Eq. (1):

$H D I=\left(I_{\text {Health }} \cdot I_{\text {Education }} \cdot I_{\text {Income }}\right)^{1 / 3}$,

where the symbol I indicates the corresponding dimension index. The cut-off points used for the four categories of human development achievements are: very high human development: $\geq 0.800$; high human development: 0.700-0.799; medium human development: 0.550-0.699; and finally, low human development: below 0.550 (UNDP, 2015). The dimensional indices (I) are calculated as:

$I=\frac{\text { Actual value }- \text { Minimum value }}{\text { Maximum value }- \text { Minimum value }}$

The IHDI is calculated as a geometric mean of the three dimension indices adjusted for inequality:

$I H D I=\left(I_{\text {Health }}^{*} \cdot I_{\text {Education }}^{*} \cdot I_{\text {Income }}^{*}\right)^{1 / 3}=[(1-$ $\left.A_{\text {Health }}\right) \cdot\left(1-A_{\text {Education }}\right) \cdot(1-$ $\left.\left.A_{\text {Income }}\right)\right]^{1 / 3}$. HDI,

where $\mathrm{A}$ is the inequality measure used. The inequality-adjusted dimension indices (I*) are constructed for three dimensions of HDI and the whole formula, by which the HDI is multiplied, represents the loss in the HDI due to inequality and. The IHDI draws on the Atkinson (1970) group of inequality measures. The inequality measure used (see more in Drastichová, 2018) is calculated as:

$A=1-\frac{g}{\mu}$,

where $\mathrm{g}$ is the geometric mean and $\mu$ is the arithmetic mean of the distribution. The first dimension health, is represented by the indicator of life expectancy (LE, years), the second dimension - education, by indicators of expected years of schooling and mean years of schooling, and the third one - standard of living, by Gross National Income (GNI) per capita (2011 purchasing power parity (PPP) USD).
Secondly, the Happy Planet Index (HPI) is used. It should represent an innovative measure, which shows the ecological efficiency with which human wellbeing is delivered. It is a measure of progress that is focused on what matters, i.e. sustainable wellbeing for all. It compares how efficiently inhabitants of different countries use natural resources to achieve long, high wellbeing lives. The HPI is referred to as an efficiency measure, which captures the degree to which long and happy lives are achieved per unit of environmental impact. In this way, it can be regarded as the SD indicator and the measure of sustainable wellbeing. It is obvious that this measure involves the crucial aspects of quality of life and the crucial features related to it. To calculate HPI scores, the mean LE of residents of a given country is multiplied by mean experienced wellbeing of residents in this country. In the 2016 release, for the first time the main results were adjusted to reflect inequalities in the distribution of experienced wellbeing and LE within the population of each country. The resulting HPI is interpreted as the number of inequality-adjusted Happy Life Years (HLY) experienced by a typical resident in each country. The average number of inequality-adjusted HLY achieved in each country is then divided by its Ecological Footprint (EF) per capita, to detect the average number of inequality-adjusted HLY produced per unit of demand on the natural environment from the residents of a country (Abdallah et al., 2012; NEF, 2016):

$H P I \approx$

Experienced Wellbeing $x$ Life Expectancy $\times$ Inequality of Outcomes Ecological Footprint

The final formula is exhibited by Eq. (6):

$$
\begin{aligned}
& H P I_{I A}=
\end{aligned}
$$

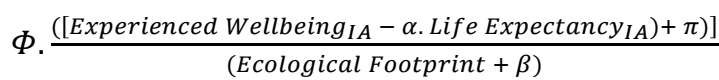

where: IA = inequality-adjusted, $\alpha=0.158, \beta=$ $2.067, \pi=3.951, \Phi=0.452$.

The inequality-adjusted experienced wellbeing scores (where Eq. (4) is used for its calculation as well) are adjusted so that their coefficient of variance is equivalent to the coefficient of variance of the inequality-adjusted LE scores. This involves subtracting a constant from the inequality-adjusted experienced wellbeing of each country, i.e. constant $\alpha$ in Eq. (6). This ensures that each of these two variables contribute the same amount of variance to the product term, which is inequality - adjusted Happy Life Years. In other words, it is achieved that the HLY measure is equally sensitive to changes in inequality- 
adjusted LE and inequality-adjusted experienced wellbeing. Subsequently, the EF scores are adjusted so that their coefficient of variance is equivalent to that of the HLY measure. Similarly, this is carried out by adding a constant to the EF, i.e. constant $\beta$ in Eq. (6). Therefore, it is achieved that the overall HPI score is equally sensitive to changes in the HLY measure and in the EF. Two scaling constants, i.e. $\phi$ and $\pi$, are also incorporated in Eq. (6) in order to achieve that the HPI score of 100 would indicate excellent performance on all the three indicators. This is the situation when the inequality-adjusted LE reached 85 years, the maximum score for inequalityadjusted wellbeing (10/10) was achieved and the EF exhibited 1.73 gha, which was determined as the level of demand compatible with environmental sustainability. On the other hand, the HPI score of zero indicates the inequality-adjusted LE of 25 years, the minimum score for inequality-adjusted experienced wellbeing $(0 / 10)$, and the EF of 16 gha, which is currently a higher level than in any single country in the world.

The EF indicator serves as one of the primary guides for the evaluation if the examined agents operate at a sustainable level (Rees and Wackernagel, 1994). It is referred to as a method for estimating the biologically productive area that is necessary to support current consumption patterns, given prevailing technical and economic processes (technology and resource management practices) (see more in Drastichová, 2018). The HPI shows how people's lives are going by means of measuring how long people live, how people are experiencing their lives directly, and by capturing the inequalities in those distributions instead of just using the averages. It also involves measuring the resource use to meet the peoples' needs (Jeffrey et al., 2016) and thus, to achieve these results, using the EF indicator, which reflects the environmental sustainability.

As the third indicator variable, Healthy Life Years (total, year) in absolute value at birth (HLY) was chosen. The indicator of HLY measures the number of remaining years that a person of specific age is expected to live without any severe or moderate health problems. On the other hand, LE at birth is defined as the mean number of years that a new-born child can expect to live if subjected throughout his life to the current mortality conditions. It is one of the most frequently used health status indicators and in this analysis, it is used as one of the explanatory variables reflecting health status. The LE indicator is included in the SDG 3 topic (good health and wellbeing) of the EU Sustainable Development Goals (SDG) indicator set (see more in Drastichová and Filzmoser, 2019). While LE clearly refer to quantitative aspects of life, HLY also indicates qualitative aspects. LE is not able to show whether extra years of life gained through increased longevity are spent in good or bad health. Therefore, indicators of health expectancies, such as healthy life years have been developed. HLY focuses on the quality of life spent in a healthy state, rather than the quantity of life, as measured by LE (Eurostat, 2020). It was considered desirable to include both types of indicators in the analysis. HLY was included in order to more clearly reflect the aspects in SDG 3. As regards the relationships between LE and HPI, LE is also a part of HPI, but combined with the experienced wellbeing and weighted in order to create this composite indicator, so there is no significant correlation between HPI and LE. In the description above, the properties of these indicators related to quality of life, SD and wellbeing were outlined, so their similarities and differences. They were chosen in order to reflect as many aspects of quality of life, SD and wellbeing as possible.

The three composite indicators described above will be used as response variables in a regression setting. In the following, the explanatory variables (factors of quality of life) used in the analysis are defined and described. The knowledge from section 2.1 was used to determine the main factors of quality of life. Primarily, the variables (indicators) used by OECD (2020) to construct its Better Life Index (BLI) reflecting quality of life and wellbeing were used as explanatory variables. Several indicators were replaced with the indicators used by Eurostat (2020), more specifically, those included in the EU SDG indicator set, reflecting the EU's efforts towards achieving SDGs. These indicators represent crucial factors of quality of life according to the detailed analysis of relevant studies (see section 2.1). The main areas of quality of life according to BLI, for which the concrete indicators are chosen, are: Housing (HD, HE, RP), Income (MI, PR), Jobs (JS, ER, LU, PE), Community (QN), Education (EA, SK, YE), Environment (AP, WQ), Civic Engagement (SR, VT), Health (LE, SH), Life Satisfaction (LS), Safety (FS, HR), and Work-Life Balance (EH, CA, SE).

The data for the indicators used are available on Eurostat (2020), OECD (2020b) and UNDP (2020) and are used for the 26 countries (the sample). If data (or indicators) are missing for some countries, the most recent values (from previous years) were used in the analysis. Efforts were made to include indicators for the years or periods which are close to one another. Nevertheless, the HPI was used as one of the response variables although more recent data were not available, since this composite index significantly reflects the aspects of SD and wellbeing (both subjective and objective), and both health and environmental factors. Therefore, it can represent an important measure of quality of life.

\subsubsection{Methodology}

Principal component analysis (PCA) and regression analysis are the main methods applied in this work. PCA is a dimension-reduction tool that is applied to reduce a large set of variables to a small set that still contains most of the information. PCA is a mathematical procedure which transforms a number of (possibly) correlated variables into a (smaller) number of uncorrelated variables named principal components. The first principal component accounts for as much of the variability in the data as possible, and 
Table 1. Explanatory variables reflecting particular factors of quality of life, source: Eurostat (2020), OECD (2020b)

Dwellings without basic facilities (HD): $\quad$ Quality of support network the percentage of the population living in a dwelling without indoor flushing toilet for the sole use of their households (an average of the data available between 201216/17, 2016 - Luxembourg and the Netherlands) (1).

Housing expenditure (HE): Percentage of the household gross adjusted disposable income (2015, with the exception of 2016 for Denmark, the United Kingdom (UK); 2014 - Italy, Norway; and 2013 - Switzerland) (2).

Rooms per person (RP): Rate (number of rooms divided by the number of people living in the dwelling) (an average of the data available between 2012-16/17, pending data availability and break in the series; 2016 - Luxembourg and the Netherlands) (3).

Mean equivalised net income (Purchasing power standard (PPS) (2017) (MI): the equivalised income attributed to each member of the household (calculated by dividing the total disposable income of the household by the equivalisation factor) (4).

At risk of poverty rate (PR): cut-off point: $60 \%$ of median equivalised income after social transfers (2017) (5).

Job satisfaction (JS): Average rating of satisfaction, 16 years or over, Rating (010) (2018, Iceland - 2013) (6).

Employment rate (ER): the number of employed persons aged 15 to 64 over the population of the same age; Percentage of the working-age population (aged 15-64) (2017) (7).

Long-term unemployment rate (LU): the number of persons who have been unemployed for one year or more as a percentage of the labour force (2017) (8).
$(\mathrm{QN})$ : a measure of perceived social network support; based on the question: If you were in trouble, do you have relatives or friends you can count on to help you whenever you need them, or not? and it considers the respondents who respond positively; OECD calculations based on the Gallup World Poll (GWP) (the 3-year average 2015-17) (10).

Educational attainment (EA): to 64 holding at least an upper secondary degree over the population of the same age; Percentage of the adult population (aged 25 to 64) (2017) (11).

Student skills (SK): Students' average score in reading, mathematics and science as assessed by the OECD's Programme for International Student Assessment (PISA); (2015) (12).

Years in education (YE): the average duration of education in which a 5-year-old child can expect to enrol during his/her lifetime until the age of 39 (2016) (13).

Air pollution (AP): the population weighted average of annual concentrations of particulate matters less than $2.5 \mathrm{mi}-$ crons in diameter (PM2.5) in the air (2013) (3-year moving average) (14).

Water quality (WQ): people's subjective appreciation of the environment where they live, in particular the quality of the water; OECD calculations based on the Gallup World Poll (the 3-year average 201416) (15).

Stakeholder engagement for developing regulations (SR): the extent to which formal stakeholder engagement is built in the development of primary laws and subordinate regulations; calculated as the simple average of two compothe number of adults aged 25
Voter turnout (VT): the ratio between the number of individuals that cast a ballot during an (parliamentary/presidential) election (whether this vote is valid or not) to the population registered to vote; percentage of the population (2018 - Finland, Hungary, Italy, Slovenia; 2017 - Austria, Czechia, the Netherlands, Norway, the UK; 2016 - Germany, Iceland, Ireland, Lithuania, Slovakia, Spain; 2015 - Denmark, Estonia, Greece, Israel, Poland, Portugal, Switzerland; 2014 - Belgium, Latvia, Sweden; 2013 - Luxembourg (17).

Life expectancy (LE): how long on average people could expect to live based on the agespecific death rates currently prevailing; refers to people born today, computed as a weighted average of LE for men and women; Number of years (2016, with the exception of 2017 for France) (18).

Self-reported health (SH): the percentage of the population aged 15 years old and over who report good or better health. The WHO recommends using a standard health interview survey to measure it, phrasing the question as How is your health in general? with response scale It is very good/ good/ fair/ bad/very bad; percentage of the population (2016 with the exception of 2017 for Iceland) (19).

Life satisfaction (LS): OECD calculations based on the GWP; people's evaluation of their life as a whole (a weighted-sum of different response categories based on people's rates of their current life relative to the best and worst possible lives for them on a scale from 0 to 10 , using the Cantril Ladder (the 3-year average 2015-17) (20).

Feeling safe walking alone at night (FS): The indicator is based on the question: Do you feel safe walking alone at night in the city or area where you live? and it shows people declaring they feel safe; percentage of people aged 15 and over (the 3-year average 2015-17) (21).

Homicide rate (HR): Age-standardised rate per 100,000 population (2015 with the exception of 2016 for Austria, Czechia, Hungary, Lithuania, the Netherlands, Sweden; 2014-16 for Iceland; 2014 for France, Ireland, Portugal, Slovakia; 2013-15 for Luxembourg) (22).

Employees working very long hours (EH): the proportion of dependent employed whose usual hours of work per week are 50 hours or more; percentage of the dependent employed (2017) (23).

Frequency of participation in cultural activities in the last 12 months (cinema, live performances or cultural sites) (CA) (2015) (at least once, percentage) (24). 


\begin{tabular}{|c|c|c|}
\hline $\begin{array}{l}\text { Personal earnings (PE): the average an- } \\
\text { nual wages per full-time equivalent de- } \\
\text { pendent employee; obtained by dividing } \\
\text { the national-accounts-based total wage bill } \\
\text { by the average number of employees in the } \\
\text { total economy; then multiplied by the ratio } \\
\text { of average usual weekly hours per full- } \\
\text { time employee to average usually weekly } \\
\text { hours for all employees (2017) (9) }\end{array}$ & $\begin{array}{l}\text { site indicators (covering re- } \\
\text { spectively primary laws and } \\
\text { subordinate regulations) that } \\
\text { measure four aspects of stake- } \\
\text { holder engagement; the maxi- } \\
\text { mum score for each of the four } \\
\text { dimensions/categories - one, } \\
\text { the maximum aggregate score } \\
\text { for the composite indicator - } \\
\text { four (2017) (16). }\end{array}$ & $\begin{array}{l}\text { Frequency of participation in sport activities } \\
\text { in the last } 12 \text { months (SE) (2015) (at least } \\
\text { once, percentage) (25). }\end{array}$ \\
\hline
\end{tabular}

Notes: Following the description of the indicator, reference years or periods, as well as the number of the indicator, are indicated in brackets. Indicators highlighted in grey are from Eurostat (2020), while the others are from OECD (2020b). Detailed descriptions are available on Eurostat (2020), OECD (2020b). Moreover, two indicators were added - namely: frequency of participation in cultural activities and frequency of participation in sport activities in the last 12 months (Eurostat, 2020)

each succeeding component accounts for as much of the remaining variability as possible (Johnson and Wichern, 2007). This methodology was applied in a previous joint work by the authors (Drastichová and Filzmoser, 2019).

Regression analysis is the second main methodology applied in this paper. Since there are three response variables which should be jointly modelled with the explanatory variables, this is the setting of a multivariate regression problem. In general, the multivariate linear regression problem for responses $Y_{1}, \ldots, Y_{\mathrm{m}}$ and explanatory variables $x_{1}, \ldots, x_{p}$ is given as

$Y_{j}=\beta_{0 \mathrm{j}}+\beta_{1 \mathrm{j}} x_{1}+\cdots+\beta_{p j} x_{p}+e_{j}$

for $j=1, \ldots, m$, with the unknown regression parameters $\beta_{0 j}, \ldots, \beta_{p j}$ and the error terms $e_{j}$. The model can be written in terms of the observations, and the usual model assumptions (independence, normal distribution, homoskedasticity) are considered, see, e.g., Johnson and Wichern (2007). Traditionally, the matrix of regression coefficients is estimated by the standard least squares (LS) method. However, since the number of observations in this application is rather low compared to the number of explanatory variables, this approach may just be reasonable to fit the existing data, but it might result in a poor prediction model. Therefore, two alternative procedures are used to estimate the regression parameters. The first is Partial Least Squares (PLS) regression, where the relationship between explanatory variables and responses is modelled by fewer components (Varmuza and Filzmoser, 2009). The number of components to be used is a tuning parameter, and its choice is based on a cross-validated error measure, such as the mean squared error (MSE). A second approach is Lasso regression (Tibshirani, 1996), where a penalized LS problem is considered, with an L1 norm penalty on the regression coefficients. This has the advantage that - depending on the tuning parameter - some regression coefficients will be shrunken to zero, and thus the corresponding variables can be considered as irrelevant for explaining the response. Thus, this corresponds to a variable selection, and the resulting model should also achieve better predictive power.

\section{Results}

Section 3.1 presents the results of the PCA, while section 3.2 contains the results of the regression analyses. A detailed analysis of the results is included in both sections.

\subsection{Results of Principal Component Analysis}

By means of a PCA, important relationships between variables and also similarities and differences between countries were discovered. Figure 1 displays the results of the first two principal components (PCs), where the factors of quality of life (from Table 1) and the response variables (composite indicators) are included. This provides an overview of the data structure in terms of loadings and scores, which are jointly presented in this biplot. The first two PCs explain roughly $58 \%$ of the total variability, and thus this biplot can be well interpreted. The variables are shown by arrows and the countries by their common country abbreviations (in green). The variables are related if the arrows have small angles and they are related negatively, if the angles are close to $180 \mathrm{de}-$ grees. The orthogonal projection of countries in the variable vectors represent their values for the variables. Countries which are close together have similar behavior. One of the reasons to include the explanatory and the response variables (subsequently used for the regression analysis) was to obtain a view of how they are connected. For example, one can see that IHDI is closely related to the indicators SE, CA, QN, LS, FS, JS and WQ (positively), but negatively related to $P R$ and $A P$.

It can be seen in Figure 1 that several groups of countries could be created which can be referred to as countries having similar levels of quality of life. If these smaller groups are combined, the sample as a whole can be divided into several groups of countries with similar features in terms of quality of life. The relative differences are especially taken into account in the analysis and comparisons (the absolute differences between some of the indicators are higher than between others). Estonia, Latvia and Lithuania are close to one another which means exhibited similar values in the indicators included. The exceptions especially exist for the HE indicator values (where Latvia had one of the highest, Lithuania one of the lowest values and Estonia the lowest value in the sam- 
a

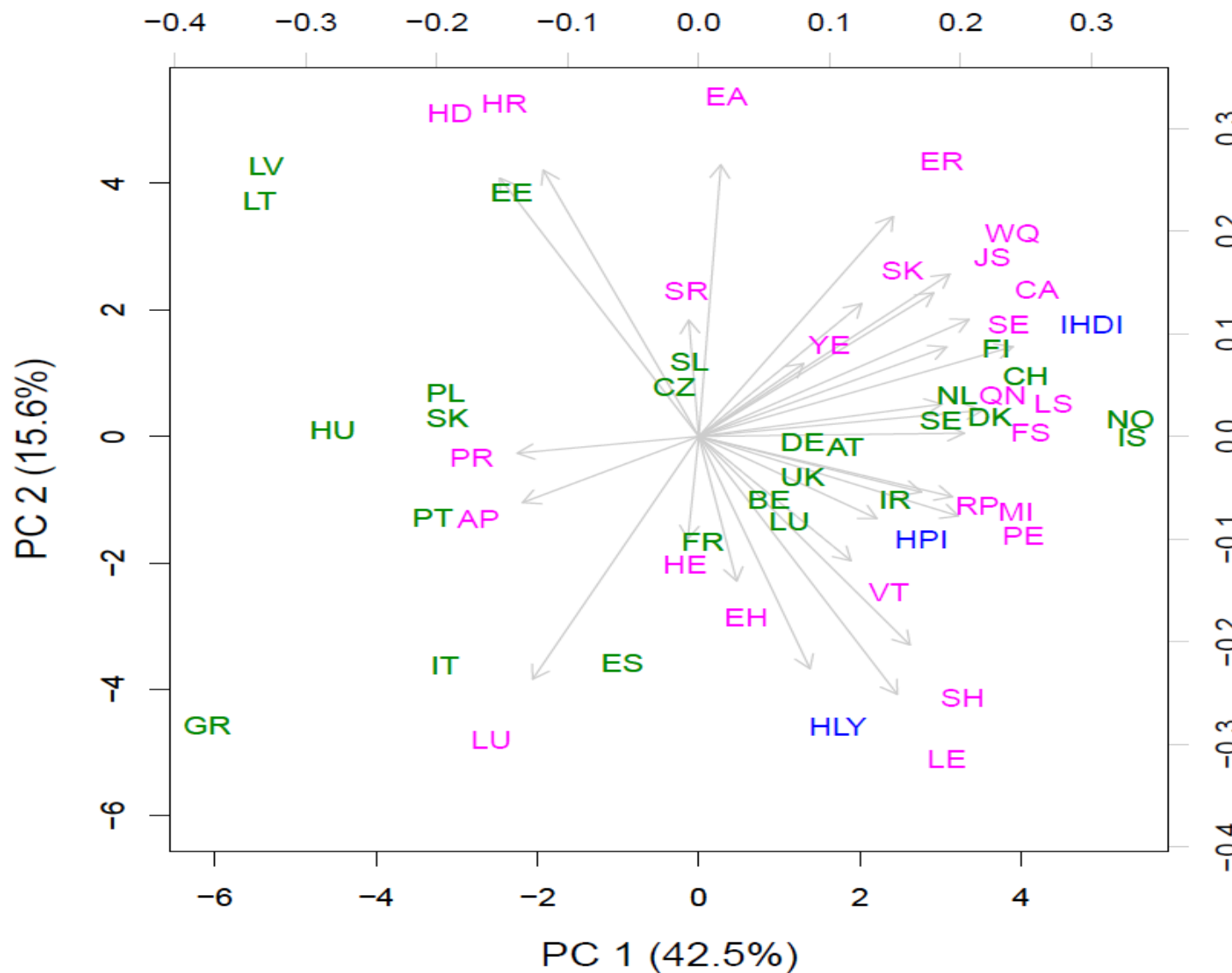

ก

$\bar{\sigma}$

웅

$\bar{i}$

$\dddot{i}$

$\stackrel{m}{1}$

官

Figure 1. The biplot created by means of the PCA, source: author's calculations

Notes: The abbreviations of countries are in black, the abbreviations of the names of 25 indicators (explanatory variables) are in red, the abbreviations of the names of 3 composite indicators are in blue.

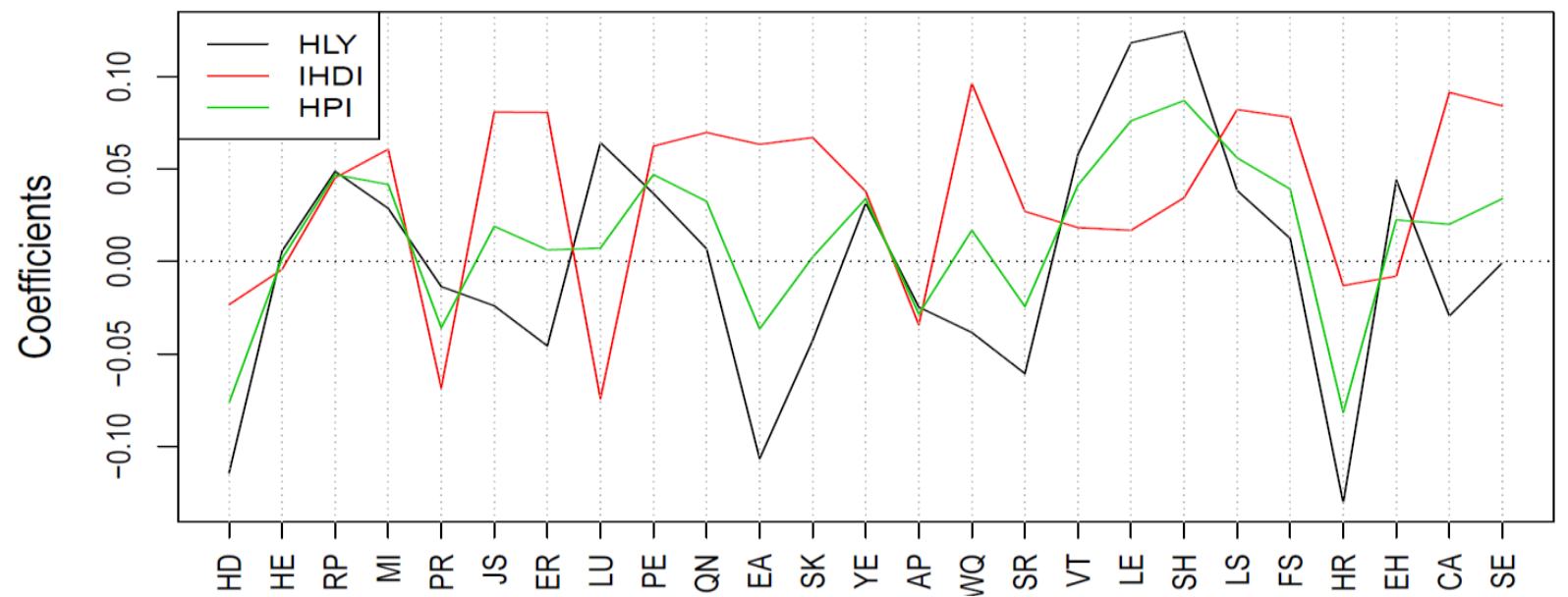

Figure 2. Regression coefficients for 25 explanatory variables - results of PLS regression, source: author's calculations

ple), the JS indicator values (where the absolute differences are small, but in relative values, Estonia had the highest and Lithuania the lowest value). In the SK indicator, Estonia exhibited the highest value in the sample, while the other two countries had among the lowest values. They also had relatively low values of three compo-site indices (response variables), with slightly higher values of IHDI in Estonia Greece, Italy and Spain also exhibited similar values of several indicators. However, HD was relatively low and FS relatively high in Spain. In the whole sample, the values of JS, ER, QN, SK, WQ and LS were the lowest in Greece. Higher relative differences were exhibited for the JS, QN, SK and LS indicators. The values of ER and WQ are among the lowest in Italy and Spain as well. On the other hand, Greece had relatively high values of YE and EH. On the other hand, YE was relatively low and SR relatively high in Italy. Spain and Italy had among the highest values of LE in the sample (following Switzerland). All three countries had among the highest HLY and among the lowest IHDI values, while the 
values of HPI differ significantly, with the lowest value in Greece (the fifth lowest in the sample) and the highest in Spain (the second highest in the sample). Other groups of countries close to one another in several values of indicators are Iceland, Norway, and Finland; and, secondly, Sweden, Denmark, and the Netherlands. Countries of these two groups are also close to one another for several indicators. The Northern countries are often close to one another in different variations. Denmark and Finland are very close to one another (they also have similar values of the response variables), and it is also the case for Denmark and the Netherlands.

In a number of indicators, Slovakia, Hungary, and Poland are similar to one another; as is Czechia to Slovenia. Again, countries of both groups exhibited similar values for certain indicators. The HE indicator is one of the major exceptions with low values in Hungary and Slovenia and relatively high values in the remaining three countries. Slovakia also exhibited the fourth highest LU in the sample (following three Southern countries), which is a significantly higher values than in the remaining fourth countries. Austria and Ireland had often similar values of the indicators included. However, as regards the response variables, Ireland had a significantly higher value of HLY and a slightly higher value of IHDI. The value of HPI was slightly higher in Austria. Higher differences between these countries especially exist for MI, VT and both environmental indicators - AP and VQ (higher in Austria) and RP, ER, LU, QN, SH and SK (higher in Ireland). Germany is close to Austria as well (from the relative point of view more significant differences between them especially exist for HD, JS, FS, EH (higher values in Austria), SK, YE, HLY (higher values in Germany). From the response variables used, only HPI was slightly higher in Austria. Germany is also close to Ireland, albeit to a slightly lesser extent for several explanatory indicators. Nevertheless, these two countries exhibited very similar values for all three composite indices (with Ireland exhibiting higher values for all three indices). Therefore, Austria, Germany and Ireland can be assigned to a group with similar features and levels of quality of life. These countries are also close other groups, especially to the group containing the Netherlands, Sweden and Denmark. For several indicators, particular countries from both groups are close to one another. Most often, Germany is close to the countries of the second group.

France and the UK are close to one another in several instances (the exceptions mainly include the HE, PR, ER, QN, SR and FS indicators (higher values in the UK) and LU and VT (higher values in France). For several indica-tors, Luxembourg and Belgium are also close to each other. Countries from these two groups are often close to one another for different variations. Luxembourg had the highest values of MI and PE. In these features, it is close to Switzerland which had the second highest values. This is also the case for LE, where Switzerland had the highest value and it is followed by Spain, Italy and Luxembourg.
On the other hand, Luxembourg followed by Belgium, and the group consisting of Sweden, Denmark and the Netherlands, exhibited the highest values of VT, while Switzerland had the lowest level. In some cases, Portugal, which often stands alone (with no close similarities to other countries), is close to them for several indicators, especially France (for HE, RP, JS, LU, QN, SK, YE, EH and Se, among others). To sum up, some countries are close to one another, i.e. they exhibit similar values for a number, or the majority, of the included indicators, signifying similarities in quality of life achieved. Geographical closeness plays a role, but it is not necessarily decisive.

\subsection{Results of Regression Analysis}

Firstly, PLS regression was carried out with all 25 explanatory variables and the three composite indicators as responses, where we first scaled the variables in order to make the resulting regression coefficients comparable. Figure 2 contains all regression coefficients for 25 explanatory variables and 3 response variables applied (the concrete coefficient values are included in the Annex, Table 1).

For all three response variables, the coefficients are negative only for $\mathrm{HD}, \mathrm{PR}, \mathrm{AP}$ and $\mathrm{HR}$, and positive for RP, MI, PE, QN, YE, VT, LE, SH, LS and FS. Rooms per person (RP) is the first indicator, reflecting housing, which has the positive coefficients for all three response variables. Next, the indicators of mean equivalised net income (reflecting income), quality of support network (QN) (reflecting community), personal earnings (PE) (reflecting jobs), years in education (YE) (reflecting education), voter turnout (reflecting civic engagement), life expectancy (LE) and self-reported health (SH) (each reflecting health), life satisfaction (reflecting itself), and the indicator of feeling safe walking alone at night (reflecting safety) also have positive coefficient values. In addition, at risk of poverty rate, (representing income), air pollution (representing environment), and homicide rate (HR) (reflecting safety), also had negative value coefficients for all three response variables.

All these results are justifiable in terms of quality of life. As regards housing (an important factor of quality of life), the first variable, dwellings without basic facilities (HD), exhibits a negative relationship with the response variables and negatively affect quality of life. For the second variable reflecting housing, i.e., housing expenditure (HE), a negative relationship was identified only for IHDI; nevertheless, all coefficients for the remaining two response variables were very low. In the group of the developed countries, poverty rates are relatively low in general. A negative relationship between PR and all three response variables was confirmed. This negative relationship is clearly seen in the Baltic countries, having the highest poverty rates and low values of the response variables, while the opposite is especially true for Iceland and Norway. However, the value of the coefficient for HLY is low in the absolute value. The three Southern countries with high HLY values (Greece, Italy, Spain) had among the highest poverty 
rates. The four countries of the Visegrad Group, Denmark and Finland exhibited low poverty rates but the HLY values are low (Finland, Slovakia) or medium (the other four countries).

With regard to the indicators representing the factor of environment, a negative effect was identified for air pollution (AP), while a positive effect was identified for water quality (WQ). The exception is the relationship between WQ and HLY, where a negative relationship was identified. The reason is especially a negative relationship in some countries of the sample, such as the Southern countries, which had high values of HLY and low values of WQ. The opposite is especially true for Austria, Slovenia, Finland or Slovakia. In the area of health, both the objective and subjective indicator reflecting health status exhibit positive coefficient values with all response variables. Life satisfaction (LS) is the only indicator reflecting the area having the same name and its positive relationship with all three composite indices is of great importance. Quality of support network (QN) is a subjective indicator based on GWP, the positive coefficient for HPI is especially justifiable and for the other two response variables the positive values were exhibited as well. The importance of two indicators from the area of safety was also confirmed. The positive relationship of the FS indicator and the negative relationship of the HR indicator with all three response variables are evidence of the significance of safety for quality of life. Job satisfaction (JS) and employment rate (ER) exhibited negative values for HLY used as a response variable (JS and ER are relatively low in the Southern countries which show high values of HLY). The positive values are justifiable for the remaining two indices. Since HPI contains subjective wellbeing in the nominator, the JS indicator should positively contribute to its higher level. Student skills (SK) seem to have a positive effect on IHDI and HPI, but not on HLY. By the detailed examination of the sample, even the negative relationship can be confirmed (in the compliance with the negative coefficients). For example, the Southern countries and Iceland exhibited low values of SK and high values of HLY. Finland, Estonia and Slovenia had among the highest SK values, but their HLY values were among the lowest. The remaining indicator representing education, educational attainment (EA), exhibited a positive relationship only with IHDI. In this sample it can especially be related to very low values of EA in the Southern countries and Iceland, and high values in the Baltic countries, Slovakia, Slovenia, Czechia and Poland. Since HLY is high in the Southern countries, all response variables show high values in Iceland, low values in the Baltic countries (but they are not the lowest for IHDI, especially in Estonia) and some of the response variables are low in the remaining three countries, the negative relationships prevailed. Three indicators representing work-life balance predominantly had positive values of the coefficients as well. Each of them exhibited one negative value for one response variable, while all these values were very low. It is possible that between HLY and cultural activities (CA) on one hand, and between HLY and sports events (SE) participation on the other a relationship might not exist or might not be strong. Moreover, a negative relationship between the proportion of employees working very long hours $(\mathrm{EH})$ and IHDI was discovered in the sample. In a number of countries in the sample, especially those most developed, such a negative relationship is visible (Switzerland having the lowest $\mathrm{EH}$ and the third highest IHDI; similarly - the Netherlands, Sweden, Denmark, Norway and Finland have very low EH along with high values of IHDI).

As the results showed, some of the 25 explanatory variables can only be crucial for some of the response variables and finally they affect them in different directions. The results can also be explained additional factors that also determined the results. The construction of particular indicators can also play a significant role. An important conclusion is that when the three indices reflecting quality of life, wellbeing, and SD (taking into account the human development approach) are applied, indicators from the areas of housing, income, jobs, quality of support network, safety, education, environment, health, and life satisfaction are likely to affect them to the highest extent (when considering effects on all three composite indices). However, education seems to have clear positive relationship only with IHDI and the positive effects are least confirmed for the healthrelated quality of life (HLY). Nevertheless, years in education (YE) seem to have positive effects on all three response variables. Then very weak effects on the subjective index of wellbeing, HPI, were identified for two of them (YE and SK).

Next, a multivariate Lasso regression based on the same explanatory and response variables was applied which internally is performing variable selection. It can be seen in Figure 3 that only nine variables exhibited non-zero coefficients. So, from the original group of 25 indicators, only 9 indicators have an important effect on the composite indices representing quality of life. This group especially includes the indicators, which exhibited the highest coefficients in the previous regression analysis (see Figure 2 and Tables 1 and 2 in the Annex). All nine coefficients are statistically significant. This was confirmed by several tests, such as the Wilks, Pillai, Hotelling-Lawley and Roy test.

The highest positive value of the coefficient in PLS regression was found for the relationship between $\mathrm{SH}$ and HLY. The following two highest positive values were detected for LE and WQ on the one hand and HLY and IHDI on the other hand (respectively). The highest negative values were identified for the relationship between HR and HD on the one hand and HLY on the other hand. As Figure 3 shows, many similarities can be found when Lasso regression is applied. The highest positive coefficients were detected for self-reported health $(\mathrm{SH})$, water quality (WQ) and life satisfaction (LS) (for HLY and IHDI as response variables respectively). The high- 


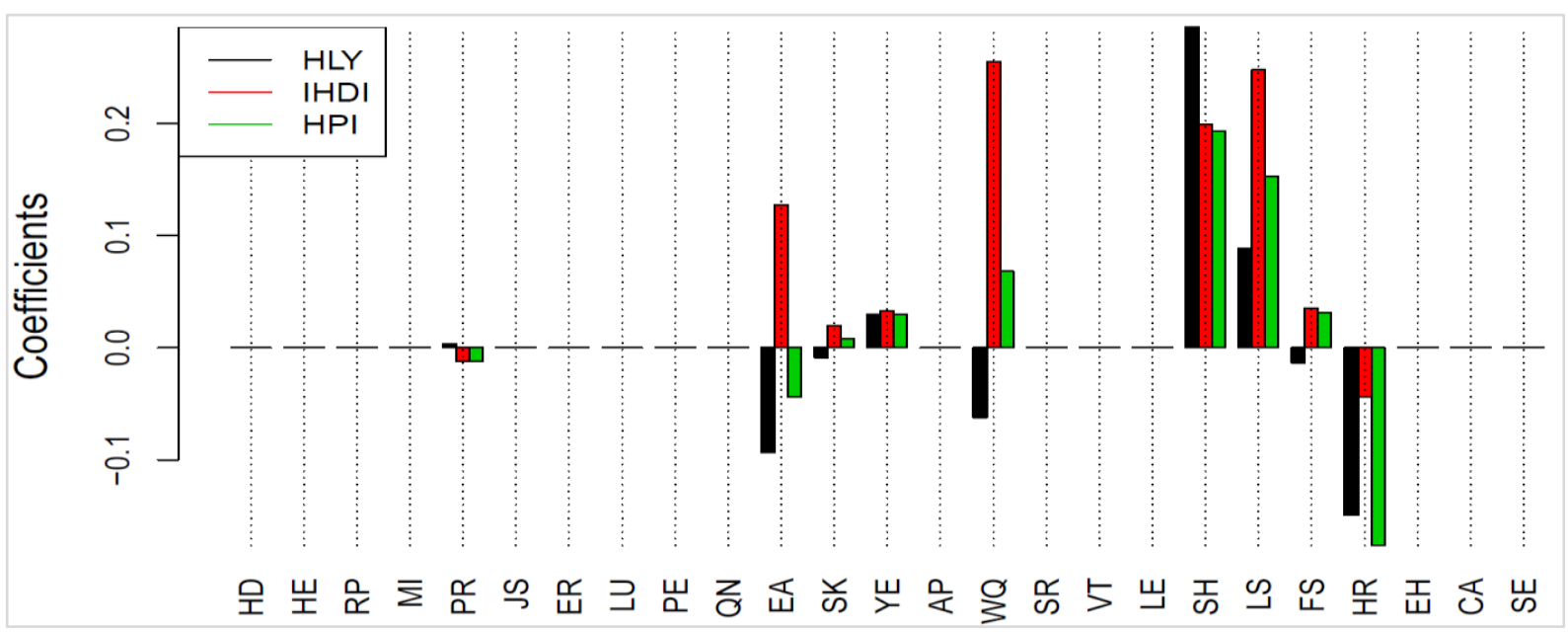

Figure 3. The non-zero regression coefficients - results of the Lasso regression, source: author's calculations

est negative coefficients were confirmed for the homicide rate (HR) indicator, especially when using HLY and IHDI as response variables.

A clear positive relationship exists between years in education (YE), life satisfaction (LS), self-reported health $(\mathrm{SH})$ on the one hand and all three response variables on the other hand. A clear negative relationship between the homicide rate (HR) indicator and the indices used as response variables was detected. Except for IHDI, the coefficients are among the highest. The reason is that the negative relationships are not strong in all countries or they do not exist at all (for example, Finland has both high IHDI and relatively high $\mathrm{HR}$, while the opposite is true for Italy). However, in a number of countries, the relationships are clearly visible, such as in the Baltic countries and Portugal, which have the highest HR values. Similar results were detected for PLS regression and therefore, these four indicators can be regarded as crucial for quality of life reflected by the three indices applied.

In the Lasso regression model the direction of relationships is also not always the same, i.e. the coefficients of several explanatory variables have different signs for different response variables (PR, EA, SK, WQ and FS). For FS, a slight negative coefficient was identified for HLY. It was already explained above that there is a number of countries that exhibited negative relationships between FS and HLY. As regards IHDI, Spain had relatively low IHDI and relatively high FS. Considering the results of both models and the fact that HLY is a more narrowly focused indicator (mainly reflecting quality of life related to health), this indicator can also be regarded as one of the crucial aspects of quality of life. Educational attainment (EA) significantly determines IHDI, but for the remaining two response variables, a negative relationship was identified (in the PLS regression analysis as well - see Figure 2). The relationships between variables in particular countries were explained above. For the SK and WQ indicator, the results are also similar to the previous PLS regression model. The explanation of the negative coefficients for HLY is similar to the case of previous two indicators. Namely, HLY is more specific, mostly related to health, when compared to other two composite indicators. As it has already been explained, there are negative relationships in some countries between HLY and these indicators which is especially the case for three Southern countries - Greece, Italy and Spain. As regards poverty rates (PR) the coefficients are low in absolute values when applying Lasso regression. When compared to the results of the PLS regression models, the coefficients are lower in absolute values for both IHDI and HPI and for HLY a very low positive value was measured. The reason is similar - as it was explained for the previous four indicators, when HLY is used as a response variable the results often differ due to high HLY values in the Southern countries and relatively low performance in many other areas of quality of life. Different signs for several coefficients can be explained by the presence of the countries whose relationships between the explanatory and response variables to some extent deviate from the majority of the countries in the sample or additional factors that also determined the results.

Next, predictions for both regression analyses are displayed to see how well these models represent the measured values of the composite indicators. For the PLS mode, two PLS components have been used. Figure 4 displays predictions from PLS regression here the 3 response variables were explained by contributions from all 25 explanatory variables.

Figure 5 displays the predictions from Lasso regression - here only 9 variables corresponding to nonzero coefficients contributed to the explanation of the three responses.

The plots in Figure 4 and 5 show the measured responses versus their predictions, and the line indicates equality of the values. Generally, both models yield similar predictions, and the prediction quality for the response IHDI is the best one. The Lasso model overestimates slightly the lower values, but also the PLS model reveals more variability in the prediction of the lowest values. For the indexes HLY 

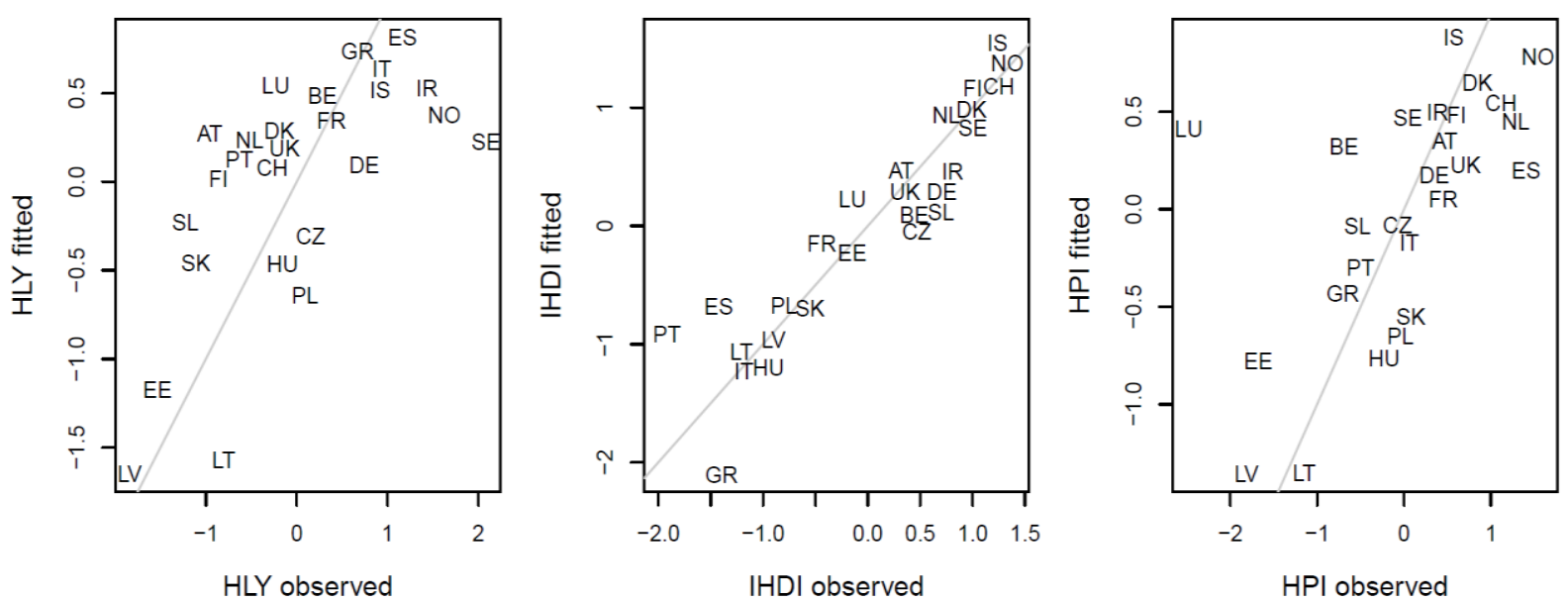

Figure 4. Predictions from PLS regression with the coefficients from Figure 2, source: author's calculations

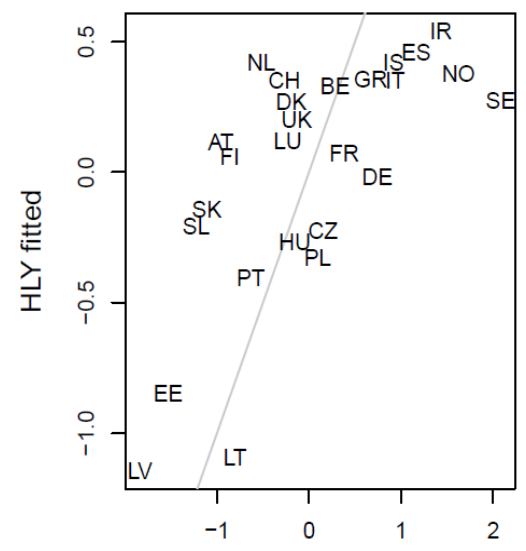

HLY observed

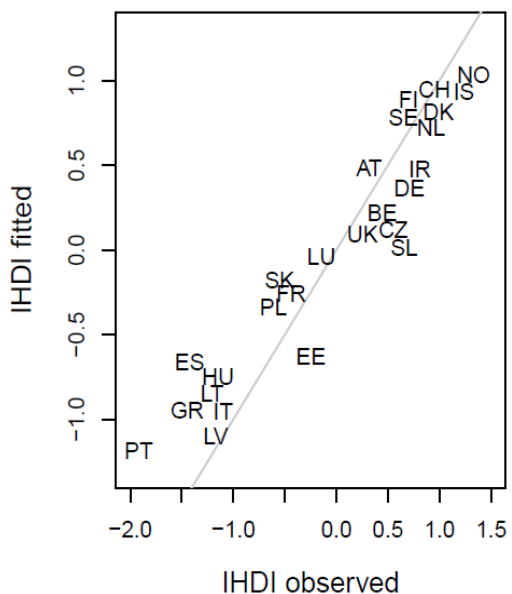

IHDI observed

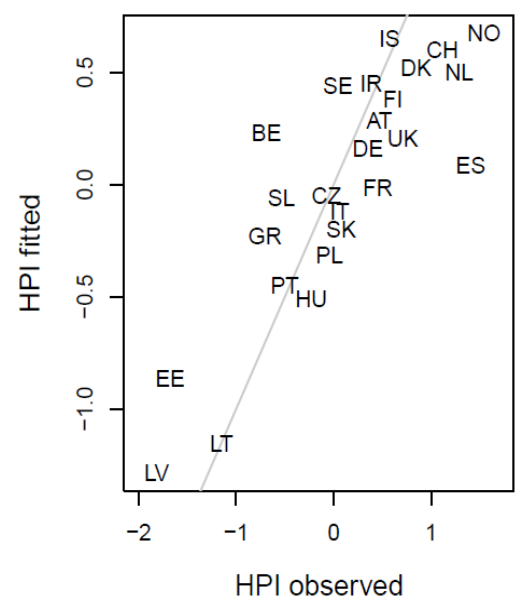

HPI observed

Figure 5. Predictions from LASSO regression with the coefficients from Figure 3, source: author's calculations

and HPI, both models deliver very similar prediction with the exception of the prediction for Luxembourg, which is far off for the PLS model. It seems that Luxembourg had a certain effect on the PLS model, most likely because some explanatory variables had unusual values. This effect could be suppressed in the Lasso model.

Overall, it is obvious that relationships exist between the composite indicators chosen as response variables to reflect quality of life, wellbeing and SD (taking into account the human development approach), and the indicators reflecting the selected factors of quality of life. However, some of the indicators affect these indices and quality of life more significantly. Accordingly, some factors are more crucial for quality of life.

\section{Discussion}

The quality of life is a key element of social planning, the aim of which is to promote and enhance the quality of life of an individual; of a family or inhabitants of a municipality, region, state and nation; and of the world by reducing detrimental conditions over a given time. In this direction, the SD and environ- mental justice approach would positively work in maintaining and promoting the quality of life of people. There has been a deficiency of studies on quality of life in the field of geography. The factors of space, time, and society, the main domain of geographers, are significant to quality of life. Geographers should, therefore, pay more attention to this topic (Sinha, 2019), as should scientists from other disciplines. The focus should be on adequate planning of health, educational, and safety services and facilities, in addition to the aforementioned crucial factors of quality of life. The idea of SD should be a central philosophy of this planning and its principles and practical approaches putting the concept of SD into operation should be applied (see more in Drastichová, 2018). The problematic aspects revealed in relation to the concept of quality of life and its measurement should not mean that improvements in quality of life are unnecessary. Rather, there is a need for place- and culture-specific measures. Although it is a multidimensional concept, achieving progress in quality of life through SD is a necessary goal (Fischer and Adjo $2011,40)$. However, a one-size-fits-all approach to SD and quality of life is not an appropriate one. The success of SD initiatives depends on how closely 
they comply with and contribute to a sense of place in a given space. A sense of belonging also contributes to overall quality of life. After the detailed studies of relevant works and the analysis carried out in this work, it can be concluded that the concepts of quality of life and SD are interconnected and efforts to improve one may well positively affect the other as well (see also Cusack, 2019).

It is highly likely that many indicators related to SD, wellbeing, and quality of life will change significantly following the current pandemic situation. This includes economic (economic recession, economic problems generally etc.), social (especially with regard to health, poverty, and social inclusion), and environmental indicators (in which although there may be positive short-term changes, the long-term impacts are not clear), as well as those indicators generally related to quality of life and wellbeing. The concepts of SD and quality of life, as well as policies towards them, must further take into account and engage with these aspects. They should be adjusted to the new development and challenges affecting sustainability, SD, quality of life and wellbeing.

New, alternative and complementary concepts should be considered when dealing with SD, quality of life and wellbeing. Innovative ideas and strategies but also systemic changes in the longer period should be included. Not only the concept of Human Development but also the concepts of Degrowth or Buen Vivir should be considered. Ecological economics can provide a platform for a transformation towards a new socio-economic model respecting the environment (biophysical planetary boundaries), and improving wellbeing and quality of life (challenging current forms of economic growth and taking the above-mentioned concepts into account). As recent developments have shown, functioning health and social systems are essential for SD, wellbeing and quality of life, and this will be a crucial challenge for the near future.

\section{Conclusions}

The quality of people's lives at a national level was the main area of interest in this work, which considers the basic philosophy of SD. The aim of this work was to identify the crucial factors affecting quality of life, and to discover the relationships between these factors in the sample of 26 developed OECD countries. PCA with both explanatory and response variables, PLS regression and Lasso regression were the main methods applied.

The factors of quality of life included housing, income, jobs, community, education, environment, civic engagement, health, life satisfaction, safety, and work-life balance. Quality of life, which should result, ultimately, from $\mathrm{SD}$, is, like SD, a global challenge. To this end, several composite indices reflecting crucial aspects of sustainability, SD, and quality of life, were selected and further used as response variables, i.e., those reflecting quality of life in conjunction with SD. In the case of both the 25 explanatory and 3 response variables, the essential aspects and factors of both quality of life and SD are reflected, based on detailed studies and analysis of relevant research works.

PCA provided an overview of the data structure and the groups of countries with similar features and levels of quality of life were identified. The plot of the first two PCs explains roughly $58 \%$ of the total variability. Geographical closeness plays a role, but it is not necessarily decisive. The most important (bigger) groups identified are the Baltic countries; three Southern countries (Greece, Italy and Spain); Slovakia, Hungary and Poland, along with Czechia and Slovenia; Iceland, Norway and Finland, along with Sweden, Denmark, and the Netherlands; or Austria, Germany and Ireland. Some similarities can also be seen between France and the UK, or between Luxembourg and Belgium. Portugal does not exhibit significant similarities to any country in the sample, but some similar features were identified, especially to France.

Subsequently, the relationships between the explanatory and response variables were identified by means of PLS and Lasso regression. Lasso regression had the advantage that the most important variables related to the responses could be identified. The direction of the relationship between particular explanatory and response variables was not always the same, i.e., the coefficients of several explanatory variables had different signs for different response variables. Since the sample is composed of developed countries, some relationships are weaker, because all these countries have already achieved a relatively high performance in indicators reflecting quality of life.

The Lasso regression model identified nine indicators which were all significant. When the three indices reflecting quality of life, wellbeing, and SD (taking into account the human development approach), namely HLY, IHDI and HPI are applied as response variables, indicators from the areas of income (at risk of poverty rate (PR), education (educational attainment (EA), student skills (SK) and years in education (YE), environment (water quality (WQ), safety (feeling safe walking alone at night (FS) and homicide rate (HR), health (self-reported health $(\mathrm{SH})$, and life satisfaction (representing the dimension of the same name, (LS) are likely to affect them to the highest extent. As regards the factor of income, only the indicator reflecting the risk of poverty (PR) had negative relationships with IHDI and HPI. All three indicators included in the factor of education, i.e. educational attainment (EA), student skills (SK) and years in education (YE), are in the group of crucial set of nine indicators, while only YE exhibited positive relationships with all three response variables. All three indicators affected positively only IHDI, which is justifiable. Student skills (SK) also had a very slight positive relationship with HPI. As regards the factor of environment, the indicator of water quality (WQ), composed as a subjective indicator, seems to be more important than the objective indicator of air pollution (AP). However, a positive relationship cannot be proven between WQ and HLY. 
Self-reported health (SH) and life satisfaction (LS) exhibited a clear positive relationship with all three response variables in both PLS and Lasso regression analysis, while their coefficients were among the highest. This also confirms the importance of subjective indicators for quality of life, since all WQ, SH and LS are constructed as subjective indicators. A negative relationship between the homicide rate (HR) indicator and all three response variables used was confirmed in both PLS and Lasso regression models (they had among the highest absolute values, except those for IHDI). The indicator of feeling safe walking alone at night exhibited a positive relationship in both models (apart from the value for HLY in the Lasso regression model). Since the last two indicators represent the factor of safety, it seems that this factor can have a significant effect on quality of life.

The PLS regression model detected the importance of indicators representing the factors of housing, income, community, jobs, education, environment, civic engagement, health, life satisfaction and safety. Particularly, the indicators of rooms per person (RP) (reflecting housing), mean equivalised net income (reflecting income), quality of support network (QN) (reflecting community), personal earnings (PE) (reflecting jobs), years in education (YE) (reflecting education), voter turnout (reflecting civic engagement), life expectancy (LE) and self-reported health (SH) (each reflecting health), life satisfaction (reflecting itself), and the indicator of feeling safe walking alone at night (reflecting safety) had positive coefficient values for all three response variables. At risk of poverty rate, (representing income), air pollution (representing environment), and homicide rate (HR) (reflecting safety) had negative value coefficients for all three response variables. So, the crucial six factors resulted from both analyses. Additional factors to those resulting from the Lasso regression model, i.e. housing, community, jobs and civic engagement also play their important role. The weakest (but not insignificant) effect on quality of life was identified for the indicators reflecting work-life balance.

In both regression models, the coefficients for HLY exhibited opposite signs for a number of variables. This is explained as by the specificity of this index in terms of quality of life and therefore, the factors of quality of life in broader terms does not need to affect this indicator significantly, especially in the group of developed countries, where the performance in many areas of quality of life is generally relatively high. Moreover, there are frequently a number of countries in which the relationships between the response and explanatory variables vary from the majority of the countries in the sample. Three Southern countries, i.e. Greece, Italy and Spain, exhibited high HLY values, Spain also the highest HPI. On the other hand, all three countries had very low IHDI values and poor performance in a number of indicators of quality of life. Switzerland, having high performance in many aspects of quality of life, high IHDI and HPI, had, on the other hand, relatively low HLY. The three Baltic countries, i.e. Latvia, Lithuania, and Estonia, exhibited poor performance in a number of indicators and in all three explained variables. However, their performance was relatively high in the two indicators reflecting education.

The two research questions we posed were confirmed. Firstly, there are many factors of quality of life, but some of them are more significant than the others. Both the PLS and Lasso regression models detected the crucial factors and indicators relevant for quality of life. Health is a crucial factor of quality of life, wellbeing and SD. Subjective indicators from several areas of quality of life (environment (WQ), health $(\mathrm{SH})$, life satisfaction (LS) are of great importance. Although life expectancy (as an objective indicator of health) had positive relationships with all three response variables in the PLS regression analysis, it was not identified as a crucial factor by means of the Lasso regression. So, it was demonstrated in this work that subjective indicators in the developed countries can be even more important since objective indicators have already achieved satisfactory levels. It is taken into account that the significance of factors is in compliance with the stage of development of countries included and the response variables play a role as well (although they were chosen carefully).

The concepts of SD and quality of life, as well as policies towards them, must further reflect new challenges and threats, especially those related to public health in the form of a current pandemic situation. They should be adjusted to a new development arising as a reaction to this situation. The importance of transformation discourses in relation to quality of life (including their application in the context of previous challenges) seems to be a challenge for future research as well.

\section{References}

1. ABDALLAH S., MICHAELSON J., SHAH S., STOLL L., MARKS N., 2012, The Happy Planet Index: 2012 Report. A Global Index of Sustainable Well-Being, London, United Kingdom: NEF (the new economics foundation), https://static1.square space.com/static/5735c421e321402778ee0ce9/t/578 de9dd29687f525e004f1d/1468918241593/2012+Ha ppy+Planet+Index+report.pdf (14.12.2020).

2. ASARA V., OTERO I., DEMARIA F., CORBERA E., 2015, Socially Sustainable Degrowth as a SocialEcological Transformation, Sustainability Science, 10(3): p. 375-384.

3. ADRIAN E. BELING, VANHULST J, DEMARIA F., RABI V., CARBALLO A.E., PELENC J., 2018, Discursive Synergies for a 'Great Transformation' Towards Sustainability: Pragmatic Contributions to a Necessary Dialogue Between Human Development, Degrowth, and Buen Vivir, Ecological Economics, 144: 304-313. DOI: 10.1016/j.ecolecon.2017.08.025

4. ATKINSON A.B., 1970, On the Measurement of Inequality, Journal of Economic Theory, 2(3): 244263.

5. BIJL R., 2011, Never waste a good crisis: Towards social sustainable development, Social Indicators Research, 102, 157-168.

6. BOTHA, F., 2016, The good African society index, Social Indicators Research, 126: 57-77. 
Annex

Table 1. Regression coefficients for 25 explanatory variables - results of the PLS regression, source: author's calculations

\begin{tabular}{|l|c|c|c|c|c|c|c|}
\hline & HLY & IHDI & HPl & & HLY & IHDI & HPI \\
\hline HD & -0.114 & -0.023 & -0.077 & AP & -0.025 & -0.034 \\
\hline HE & 0.006 & -0.004 & 0.002 & WQ & -0.038 & 0.096 & 0.017 \\
\hline RP & 0.049 & 0.045 & 0.047 & SR & -0.061 & 0.027 & -0.024 \\
\hline MI & 0.029 & 0.061 & 0.042 & VT & 0.058 & 0.018 & 0.041 \\
\hline PR & -0.014 & -0.068 & -0.036 & LE & 0.118 & 0.017 & 0.076 \\
\hline JS & -0.024 & 0.081 & 0.019 & SH & 0.125 & 0.035 & 0.087 \\
\hline ER & -0.046 & 0.081 & 0.006 & LS & 0.038 & 0.082 & 0.056 \\
\hline LU & 0.064 & -0.074 & 0.007 & FS & 0.013 & 0.078 & 0.039 \\
\hline PE & 0.037 & 0.063 & 0.047 & HR & -0.131 & -0.013 & -0.082 \\
\hline QN & 0.007 & 0.070 & 0.033 & EH & 0.044 & -0.008 & 0.023 \\
\hline EA & -0.107 & 0.063 & -0.037 & CA & -0.029 & 0.092 & 0.020 \\
\hline SK & -0.043 & 0.067 & 0.002 & SE & -0.001 & 0.084 & 0.034 \\
\hline YE & 0.032 & 0.038 & 0.034 & & & \\
\hline
\end{tabular}

Note: Fields with negative coefficient values are highlighted in grey.

Table 2. The non-zero regression coefficients - results of the Lasso regression, source: author's calculations

\begin{tabular}{|l|c|c|c|}
\hline & HLY & IHDI & HPI \\
\hline PR & 0.003 & -0.012 & -0.013 \\
\hline EA & -0.093 & 0.127 & -0.044 \\
\hline SK & -0.009 & 0.020 & 0.008 \\
\hline YE & 0.030 & 0.033 & 0.030 \\
\hline WQ & -0.062 & 0.255 & 0.068 \\
\hline SH & 0.286 & 0.199 & 0.193 \\
\hline LS & 0.089 & 0.248 & 0.153 \\
\hline HS & -0.013 & 0.035 & 0.031 \\
\hline
\end{tabular}

Note: Fields with negative coefficient values are highlighted in grey.

7. CUMMINS, R. A., 2005, Moving from the quality of life concept to a theory, Journal of Intellectual Disability Research, 49(10): 699-706.

8. CUSACK C., 2019, Sustainable Development and Quality of Life, Multidimensional Approach to Quality of Life Issues, ed. Sinha B., Springer, Singapore.

9. BELL S., MORSE S., 2008, Sustainability indicators: Measuring the immeasurable? Earthscan, London

10. BELING A. E., VANHULST J., DEMARIAC F., RABI V., CARBALLO A. E., PELENC J., 2018, Discursive Synergies for a 'Great Transformation' Towards Sustainability: Pragmatic Contributions to a Necessary Dialogue Between Human Development, Degrowth, and Buen Vivir, Ecological Economics, 144: 304-313.

11. DEVRIES B., PETERSON A., 2009, Conceptualizing sustainable development: An assessment methodology connecting values, knowledge, worldviews and scenarios, Ecological Economics, 68: 106-1019.

12. DRASTICHOVA M., 2018, The Theory and Measurement of Sustainable Development, SAEI, 52, VSB-TU Ostrava, Ostrava.

13. DRASTICHOVÁ M., FILZMOSER P. 2019, Assessment of Sustainable Development Using Cluster Analysis and Principal Component Analysis, Problemy Ekorozwoju/ Problems of Sustainable Development, 14/2: 7-24.

14. HUBERT M ROUSSEEUW P J VANDEN BRANDEN K., 2005, ROBPCA: A New Approach to Robust Principal Component Analysis, Technometrics, 47: 64-79.

15. ENGELEN S., HUBERT M., VANDEN BRANDEN K., 2005, A Comparison of Three Procedures for Robust PCA in High Dimensions, Austrian Journal of Statistics, 34: 117-126.

16. ELYSE W. K., 1992, Quality of life: Meaning, measurement, and models, Navy Personnel Research,
Arid Development Center, San Diego, California, USA.

17. EUROSTAT, 2020, Eurostat Database, https:// ec.europa.eu/eurostat/data/database (28.09.2020).

18. FARQUHAR M., 1995, Elderly people's definitions of quality of life, Social Science and Medicine, 41(10).

19. FELCE D., 1997, Defining and applying the concept of quality of life, Journal of Intellectual Disability Research, 41: 126-135.

20. FELCE D., PERRY J., 1995, Quality of life: Its definition and measurement, Research in Developmental Disabilities, 16(1): 51-74.

21. FELCE D., PERRY J., 1996, Adaptive behaviour gains in ordinary housing for people with intellectual disabilities, Journal of Applied Research in Intellectual Disabilities, 9(2): 101-114.

22. FERRANS C. E., 1996, Development of a conceptual model of quality of life, Research and Theory for Nursing Practice, 10(3): 293-304.

23. FENG C.-M., HSIEH C.-H., 2009, Implications of transport diversity for quality of life, Journal of Urban Planning and Development, 135(1): 13-18.

24. FISCHER J. M., ADJO A., 2011, Quality of life, sustainable civil Infrastructure, and sustainable development: Strategically expanding choice, Journal of Urban Planning and Development, 137(1): 3948 .

25. GALLOWAY S. 2006, Ouality of life and well-being: Measuring the benefits of culture and sport: A literature review, Scottish Executive Social Research, Edinburgh, Scotland.

26. GAMBINI B., 2006, Cultural assumptions against sustainability: An international survey, Journal of Geography in Higher Education, 30(2): 263-279.

27. GHOSH A. K.,1993, Growth of female literacy in India. University news, Monday, November 8, New Delhi. 
28. GINSBERG E., 1980, Man and his work, Managing people at work, ed. Beach D.S., Macmillan Publishing, New York.

29. GREENWOOD D. T., HOLT R. P. F., 2010, Local economic development in the 21st century: Quality of life and sustainability, M.E. Sharpe Inc., Armonk, New York.

30. HAAS B. K., 1999. A multidisciplinary concept analysis of quality of life, Western Journal of Nursing Research, 21(6): 728-742.

31. HAAS P. M., MAKAREWICZ C., BENEDICT A., et al., 2006, Housing \& transportation cost trade-offs and burdens of working households in 28 metros, Center for Neighborhood Technology, 2.

32. HUBERT M., ROUSSEEUW P. J., VERDONCK T., 2009, Robust PCA for Skewed Data and Its Outlier Map, Computational Statistics \& Data Analysis, 53: 2264-2274

33. HUSSAIN M., 1994, Human geography, Rawat Publications, Jaipur.

34. IONCICĀ D. E., PETRESCU E.C., 2016, Slow living and the green economy, The Journal of Philosophical Economics, IX(2): 85-104.

35. JEFFREY K., WHEATLEY H., ABDALLAH S., 2016, The Happy Planet Index: 2016. A global index of sustainable well-being, New Economics Foundation, London.

36. JONES E., JOHN E., 1977, An introduction to social geography, Oxford University Press, New York.

37. JOHNSON R. A., WICHERN D. W., 2007, Applied Multivariate Statistical Analysis. 6th ed., Pearson Education, United States.

38. LOTFI S., FARAJI A., HATAMINEJAD H., AHMAD P., 2011, A study of urban quality of life in a developing country, Journal of Social Sciences, 7(2): 232-240.

39. MARONNA R. A., MARTIN R. D., YOHAI V. Y., 2006, Robust Statistics: Theory and Methods, John Wiley \& Sons, Ltd.

40. MEEBERG G. A., 1993, Quality of life: A concept analysis, Journal of Advanced Nursing, 18(1): 3238, http://www.ncbi.nlm.nih.gov/pubmed/8429165.

41. MITTAL L. N., 1993, Women and the educational development processes, The university news, Monday, December 13, New Delhi.

42. MOONS P., BUDTS W., DE GEEST S., 2006, Critique on the conceptualisation of quality of life: A review and evaluation of different conceptual approaches, International Journal of Nursing Studies, 43(7): 891-901.

43. MORRILL R.W., 2011, Geography of well-being, 21st century geography: A reference handbook, ed. Stoltman J.P., Thousand Oaks, Sage Publications Inc., California, p. 367-377.

44. MOŞTEANU D., MIHÄILĂ-LICĂ G., HALMAHGI E. E., MOSTEANU R., 2014, The sustainable development-human development, Land Forces Academy Review, 19(1): 106-113.

45. NEF (NEW ECONOMICS FOUNDATION), 2016, Happy Planet Index, http://happyplanetindex.org/ 20. 12.2016

46. NUSSBAUM M., SEN A., 1993, The Quality of Life, Oxford University Press, Oxford. DOI: 10.1093/0198287976.001.0001.

47. OECD, 2020a, Executive summary, in: How's Life? 2020: Measuring Well-being, OECD Publishing House, Paris. DOI: 10.1787/ea714361-en.

48. OECD, 2020b, OECD Stat, Better Life Index, https:// stats.oecd.org/Index.aspx? DataSetCode=BLI (26.09.2020).

49. PARK K., 2009, Park's text book of preventive and social medicine, Jabalpur, M.P., Banarsidas Bharnot Publishers, India.

50. PERERA U., MENSAH C. A., 2019. Housing Affordability as a Reflexivity of Quality of Life, Multidimensional Approach to Quality of Life Issues, ed. Sinha B, Springer, Singapore.

51. PELLICER G. E., 2008, Educational changes for sustainable cities: Autonomous knowledge, Local sustainable urban development in a globalized world, eds. Heberle L.C., Opp S.M., Ashgate, Aldershot, p. 203-

52. PRUTKIN J. M., 2002, A history of quality of life measurements. Yale Medicine Thesis Digital Library, paper 424, Yale University, Yale.

53. QASIM S. Z., 1993, Science and quality of life, The Offsetters, Udaichand Marg, Kotla Mubarakpur, New Delhi, India.

54. REES W.E., WACKERNAGEL M., 1994, Ecological footprints and appropriated carrying capacity: Measuring the natural capital requirements of the human economy, Investing in Natural Capital: The Ecological Economics Approach to Sustainability, eds. Jansson, A., Hammer, M., Folke, C., Costanza, R., Island Press, Washington DC.

55. RAJESH, 1993, Population growth, environment and development, University news, Monday, Oct. 25, New Delhi.

56. RAJEV A., 2006, Geography. Ist Floor, Spectrum Books Pvt. Ltd, Janakpuri, New Delhi.

57. RAMASWAMI A., RAM N. V. R., 1985, Poverty, is it understood? Inter India Pub. New Delhi.

58. RODRIGUES J., CHICAU BORREGO C., RUIVO P., SOBREIRO P., CATELA D., AMENDOEIRA J., MATOS R. 2020, Conceptual Framework for the Research on Quality of Life, Sustainability, 12: 4911. DOI: $10.3390 /$ su 12124911

59. SARMA E. A. S., MAGGO J. N., SACHDEVA A. S., 1993, Energy, environment and quality of life, Science and quality of life, ed. Qasim S.Z., The Offsetters, Udaichand Marg, Kotla Mubarakpur, New Delhi.

60. SAXENA S., CHANDIRAMANI K., BHARGAVA R., 1998, WHOQOL-Hindi: Aquestionnaire for assessing quality of life in health care settings in India, The National Medical Journal of India, 11(4)

61. SETH J., 1889, The evolution of morality, Mind, 14(53).

62. SINHA B., 2019, Multidimensional Approach to Quality of Life Issues. A Spatial Analysis, Springer Nature Singapore Pte Ltd, Singapore.

63. SIRGY M. J., 1998, Materialism and quality of life, Social Indicators Research, 43(3): 227-260.

64. SMITH D., 1977, Human geography: A welfare approach, Edward Arnold.

65. TESTA M. A., SIMONSON D. C., 1996, Assessment of quality-of-life outcomes, New England Journal of Medicine, 334(13): 835-840.

66. TIBSHIRANI R., 1996. Regression Shrinkage and Selection via the Lasso, Journal of the Royal Statistical Society. Series B (Methodological), 58(1): 267288.

67. UNDP, 2020, Human Development Reports, http://hdr.undp.org/en/humandev (30.01.2021)

68. UNDP, 2011, Human development report 2011, Sustainability and equity: A better future for all, New York, USA.

69. UNDP, 2015, Human Development Report 2015, Work for Human Development, New York, USA, http://hdr.undp.org/sites/default/files/2015_human_ development_report.pdf (13.12.2020).

70. UNDP, 1990, Human Development Report 1990, Oxford University Press, New York, http:// hdr.undp.org/en/reports/global/hdr1990.

71. UNITED NATIONS, EUROPEAN COMMISSION, INTERNATIONAL MONETARY FUND, OECD, WORLD BANK, 2003, Handbook of National Accounting. Integrated Environmental and Economic Accounting 2003, Studies in Methods, Series F(61), rev. 1 (ST/ESA/STAT/SER.F/61/ Rev.1).

72. VARMUZA K., FILZMOSER P., 2009, Introduction to Multivariate Statistical Analysis in Chemometrics (1st ed.), CRC Press, DOI: $10.1201 / 9781420059496$

73. WCED (World Commission on Environment and Development), 1987, Our common future, Oxford University Press, Oxford, New York.

74. WHO, 1997, WHOQOL: Measuring quality of life, Division of Mental Health and Prevention of Substance Abuse, Geneva. 